\title{
EXAMINATION OF MECHANICAL AND ELECTRICAL PROPERTIES AND STRUCTURE OF SELECTED ALUMINUM ALLOY SHEETS PRODUCED FROM TRC SEMI-PRODUCTS
}

\begin{abstract}
Modern manufacturing methods of non-ferrous metals, especially aluminum and its alloys, are more and more often based on integrated technologies combining multiple operations in a single process. One of the most popular methods for producing flat components by cold working is twin roll casting technology (TRC). It allows to eliminate from manufacturing the extremely expensive hot rolling operation, as the TRC semi-product (strip) can be directly cold rolled. The results of mechanical and electrical properties and structure examination of strips after casting were presented in the paper. The effect of cold rolling parameters on post-process mechanical properties and structure of sheets was investigated too.
\end{abstract}

Keywords: aluminum, twin roll casting, cold rolling, structure, hardness, electrical conductivity

\section{Introduction}

The commonly used semi-continuous casting and hot rolling production lines for plastic processing of aluminium alloys have very high level of efficiency. Because of that, frequent modifications of production profiles or products encounter significant difficulties, both operational and technical and involve high volume of waste generation. The conventional technology is energyconsuming and requires a complex production infrastructure which decreases the competitiveness between manufacturers due to financial reasons. Many companies looking for new markets tend to focus on production of special, dedicated materials and choose smaller, more flexible production lines allowing them for quick production profile changes. The modern technologies of processing non-ferrous metals, especially aluminium alloys are more and more often based on integrated technologies, combining multiple operations in a single production line [1-3].

The new technology of manufacturing and processing selected aluminium alloys covers liquid metal preparation and its continuous casting between two turning cylindrical crystallizers (Twin Roll Casting - TRC), optional material homogenization, cold rolling and optional heat treatment between and after different operations. In the TRC method liquid metal is poured into a clearance between two powered, cylindrical-shaped crystallizers. As a result of heat exchange between the cast metal and water cooled crystallizers the metal crystallizes.

The TRC method is traditionally classified as a continuous casting method, but in reality it's a combination of continuous casting and a rolling operation under high temperature. This is a result of geometrical dimension changes between the crystallizers. Due to deflection application, the surface quality, the microstructure and the finished product properties are significantly better in comparison to those manufactured in a conventional DC process. A slimmer layer of solidifying material means less variation in crystallization speed and less segregation. Additionally, the draft reduces the risk of cracking during hot working processes. On the other hand, the material deformation caused by the crystallizer cylinders takes place under substantial temperature gradient across the layer thickness and it may result in a certain heterogeneity in deflection and material properties across the thickness [4-7].

The TRC method allows to product metal strips in different thickness variations that can be cold worked into sheets. The elimination of multiple operations associated with block processing and hot rolling significantly reduces the cost of material processing and the overall capital expenditures (hot working facilities is not required). Moreover, the products manufactured using the TRC method are likely to show better mechanical properties compared to those produced by conventional methods [8-10].

\section{Material; casting and cold working procedure}

Laboratory TRC system for metal strip production was used in the research (Fig. 1). The first stage of research covered the 


\section{Research findings and result analysis}

\subsection{Hardness tests}

the introduction of special master alloy AlFe80 (for alloy series $8 \mathrm{XXX}$ casting). Each of the alloys was carefully mixed and left in the furnace for 20 minutes to homogenize the chemical composition. After this time the casting process for each material began. The metal at the temperature of $720^{\circ} \mathrm{C}$ was transferred onto the crystallizer rolls through a deluge system, which was additionally heated up to $800^{\circ} \mathrm{C}$ to avoid potential material solidification before it would enter the clearance between the rolls. The casting speed for the examined metal strips was $0.4 \mathrm{~m} / \mathrm{min}$ and the usage of the cooling medium equaled to $22 \mathrm{l} / \mathrm{min}$. The output strips were $9 \mathrm{~mm}$ thick and $90 \mathrm{~mm}$ wide. Test specimens were taken from the strips to determine properties such as hardness, electrical conductivity and microstructure.

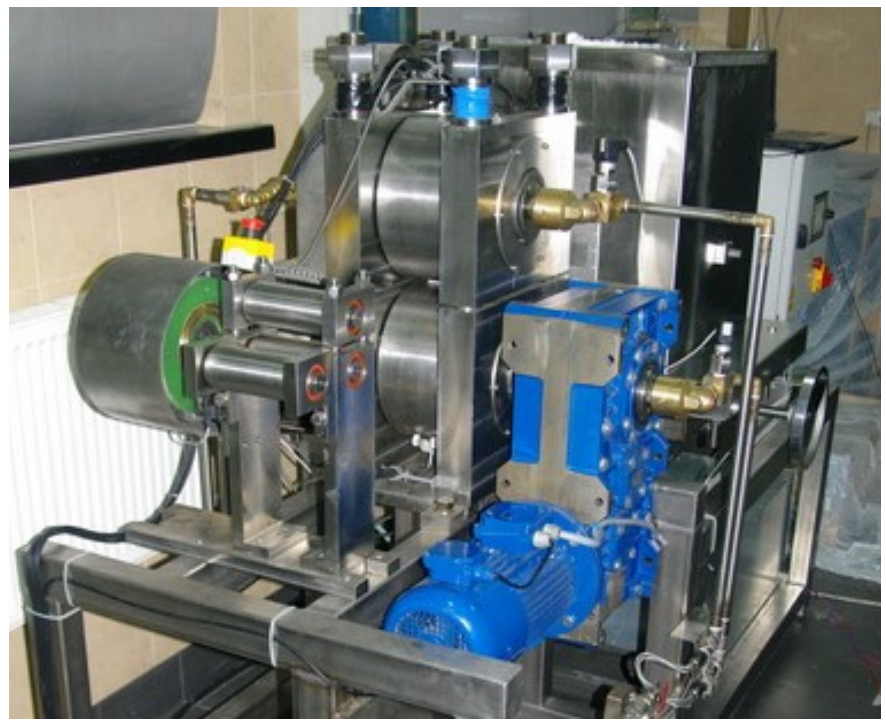

Fig. 1. The laboratory production equipment for continuous casting by the TRC method

The next stage in the research was the preparation of the test specimens for the cold rolling process. It was performed for an aluminium grade EN AW-1370 strip and two more made from alloys containing $0.4 \%$ of iron (EN AW-8176 equivalent) and $0.73 \%$ (EN AW-8079 equivalent). The operation was conducted using a laboratory four-high rolling mill. The initial thickness was $9 \mathrm{~mm}$ and after each rolling pass it was reduced respectively to $8,3 \mathrm{~mm}-7,6 \mathrm{~mm}-6,5 \mathrm{~mm}-5,4 \mathrm{~mm}-4,5 \mathrm{~mm}-3,8 \mathrm{~mm}$ $-3 \mathrm{~mm}-2,2 \mathrm{~mm}-1,5 \mathrm{~mm}-1 \mathrm{~mm}$. The forces used in the cold working process were recorded with the Spider load cells located on both rolls and the Catman software. After each rolling pass the hardness of materials was examined. Additionally, the $1 \mathrm{~mm}$-thick sheets were subjected to structural examination. The rolling forces used in the process were recorded. The initial width of the test specimens subject to cold rolling was $72.5 \mathrm{~mm}$ for the TRC strips. The diameter of the working cylinder of the mill was $60 \mathrm{~mm}$.
Hardness tests were performed for as-cast strips across their cross-sections using Vickers tester. The data was captured in $2 \mathrm{~mm}$ steps from the bottom of strip and average values from 5 measurements were calculated (Fig. 2).

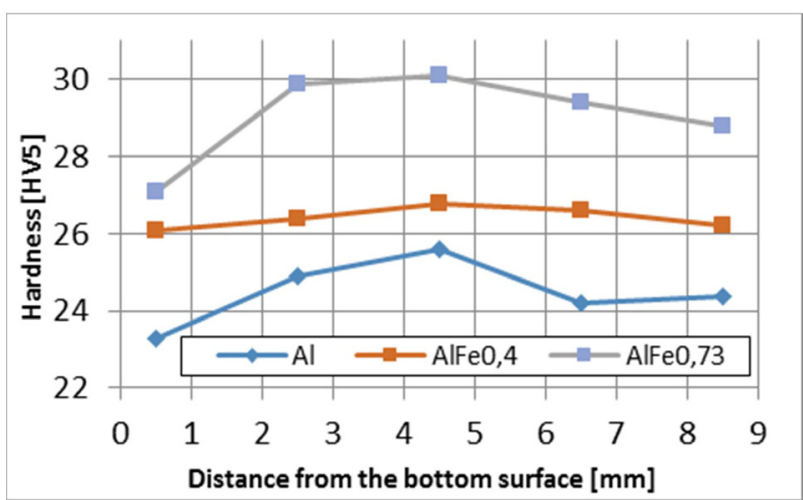

Fig. 2. Hardness across the cross-section of as-cast strips made of different materials

Presented test results (Fig. 2) clearly show that the hardness varies across the thickness of the cast strip. The values are higher in the middle sections of the strips than those recorded closer to the edges. There is a probability that this is caused by the alloying elements segregation in the centre of the cast strip and it is a premise showing the possibility of existence of normal anisotropy of mechanical properties. A noticeable difference in hardness (the average value acquired from measurements across the thickness) can also be observed after the base material - pure aluminium is enriched with extra iron. On average, this leads to hardness increase by 2 HV5 (measuring accuracy 0,1 HV5) with $0.4 \%$ Fe content and 4.6 HV5 with $0.73 \% \mathrm{Fe}$.

\subsection{Electrical conductivity tests}

The aluminium alloy series $1 \mathrm{XXX}$ as well as $8 \mathrm{XXX}$ can be used as electricity conductors, therefore an analysis was performed to show the impact of the amount of alloying elements on the electrical conductivity of the materials. The eddy-current method was used and averaged results from 10 measurements were considered in analysis (Fig. 3).

The analysis of test results allows to state that increasing Fe content in examined materials reduces their electrical conductivity, which is a natural phenomenon. The conductivity of the material containing $0.4 \%$ of Fe is reduced down to $35 \mathrm{MS} / \mathrm{m}$, whereas the material with $0.73 \%$ Fe shows $33.9 \mathrm{MS} / \mathrm{m}$. A similar reduction of electrical conductivity properties was described in $[11,12]$; the papers analyze material properties manufactured in continuous cast processes. 


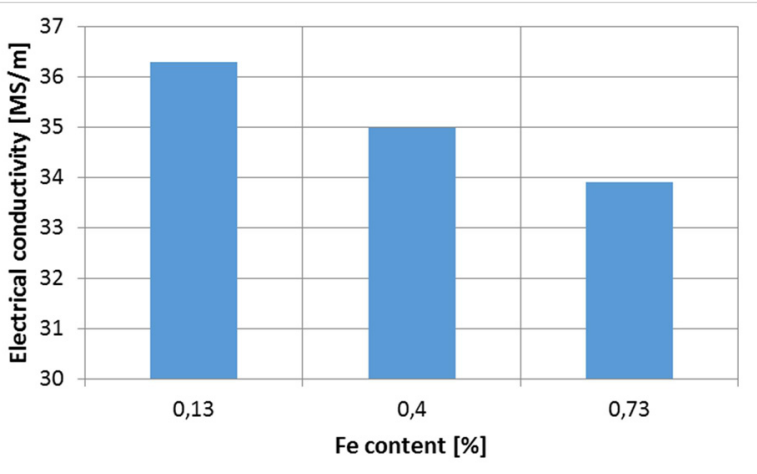

Fig. 3. Electrical conductivity of the TRC manufactured strips with different $\mathrm{Fe}$ addition

\subsection{Macrostructure examination}

Test specimens were taken from the manufactured metal strips and were subjected to the initial analysis of the alloying elements effect on the cast macrostructure (Table 1).

By analysing macrostructures of the selected materials manufactured by the TRC method one can observe that they are slightly different to the macrostructures from conventional casting methods [13]. Each of the structures in the longitudinal cross-section is composed of long column grains converging towards the middle section of the strip. The axes of the grains are at an angle with the strip axis, and the direction in which they grow coincides with the direction of the heat transfer from the metal through the liquid cooled crystallisers during solidification process (an example is shown in the Table 1 in red) and is also altered by the material deformation. The area of transcrystallisation runs near the axis through the middle section of the strip and it is a positive phenomenon proving that the structural elements of TRC machine and the process parameters have been designed correctly, as the heat reception by both crystallisers is similar. Additionally, fine equiaxed grains can be observed at the edges of the strips. They can form during material solidification as frozen crystal areas or prove that during the casting process partial material deformation under high temperature takes place (equiaxed grains can also be an effect of dynamic recrystallization, also experienced during hot rolling processes). Iron additives introduced to the base material do not cause substantial structure fragmentation, however some sources report grain fragmentation due to $\mathrm{Fe}$ addition [14].

\subsection{Microstructure examination}

Microstructure examination performed for the manufactured metal strips was carried out using an optical microscope Olympus GX51 equipped with a digital image recorder. Test specimens were taken and then impregnated in Epo Fix Kit resin. Subsequently, they were ground using abrasive papers with granularity of 220,500,800,1200, 2400 and 4000 and then subject to two-stage mechanical polishing in accordance with the Struers procedure. Suspension of diamond paste Dia Duo with grain size of $3 \mu \mathrm{m}$ and an OPS colloidal silica suspension for the finishing polishing with a grain size of $0.25 \mu \mathrm{m}$ were used. To reveal the microstructure of the samples, they were anodized in the Barker reagent, 1.8 HBF4 + $100 \mathrm{ml} \mathrm{H} 20$. The use of Barker reagent allows to visualize grains which in polarized light can be seen in different colours. Based on the findings from hardness tests and possible concentration of the iron additives near the axial area of the TRC produced strips, the examination was performed at the edge of each strip as well as at their middle sections.

The first part of examination covered the microstructure analysis using light microscope (Fig. 4-9).

TABLE 1

TRC metal strip macrostructure - longitudinal direction

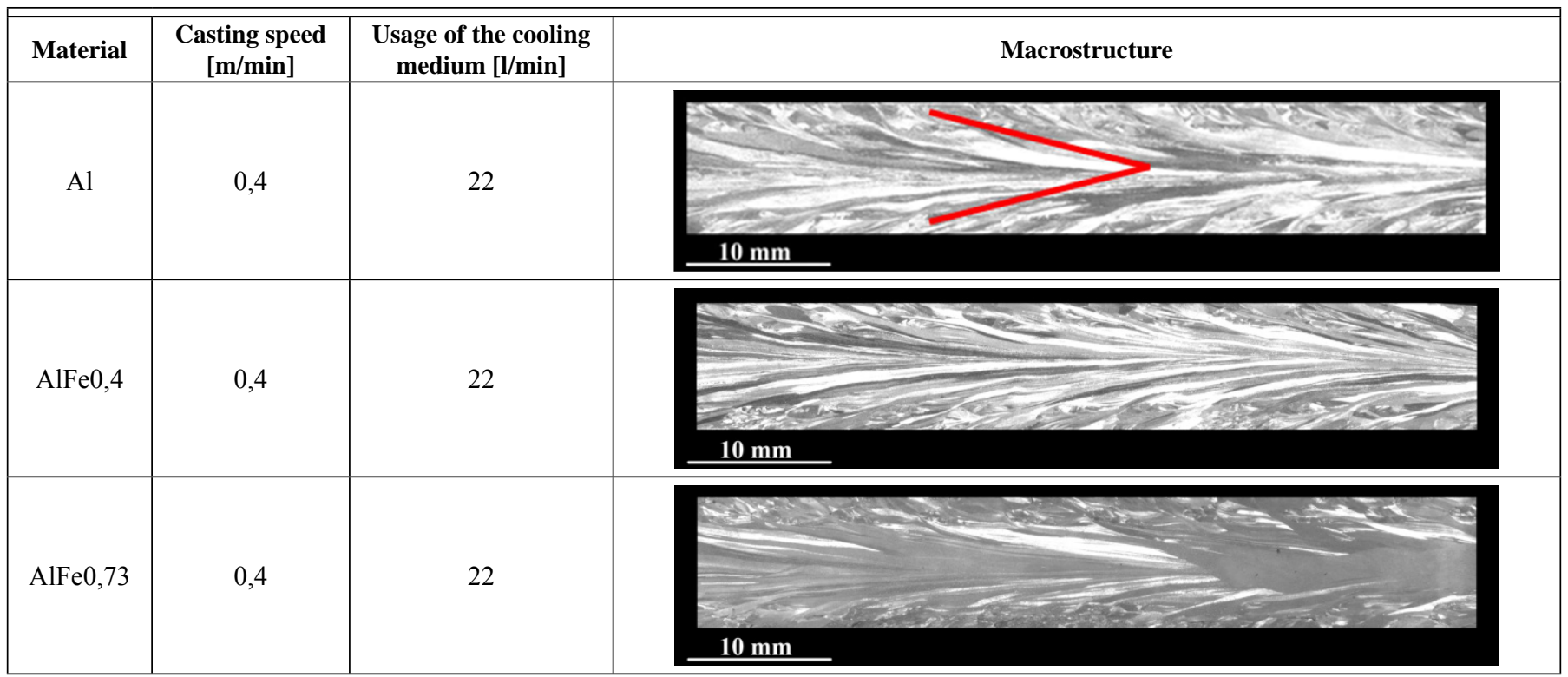



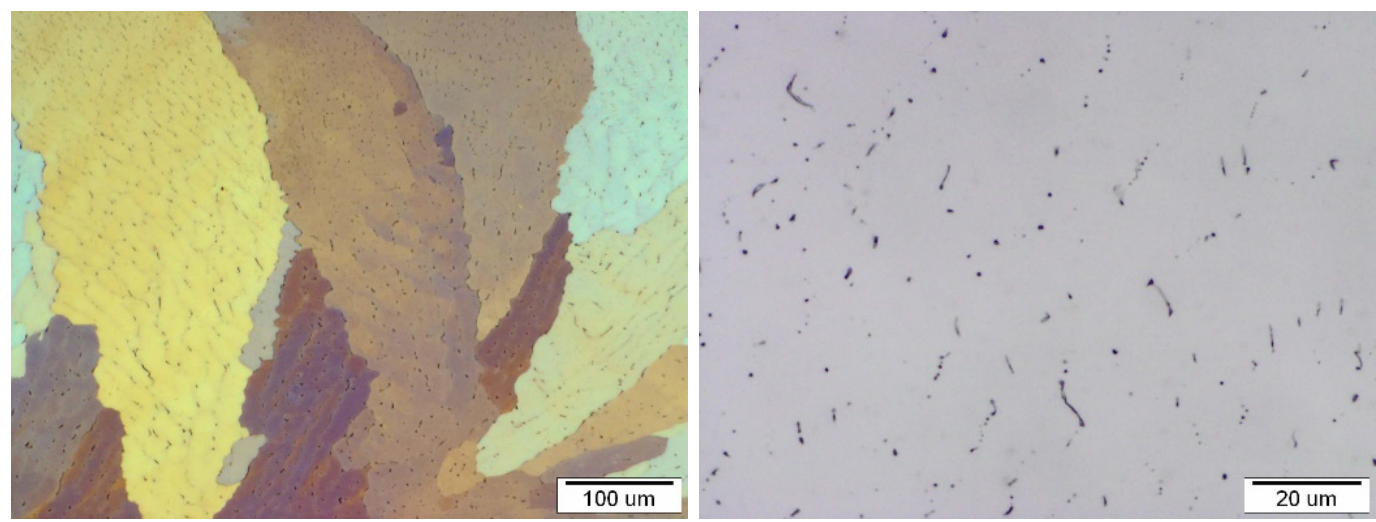

Fig. 4. Microstructure of Al observed at the edge of the strip
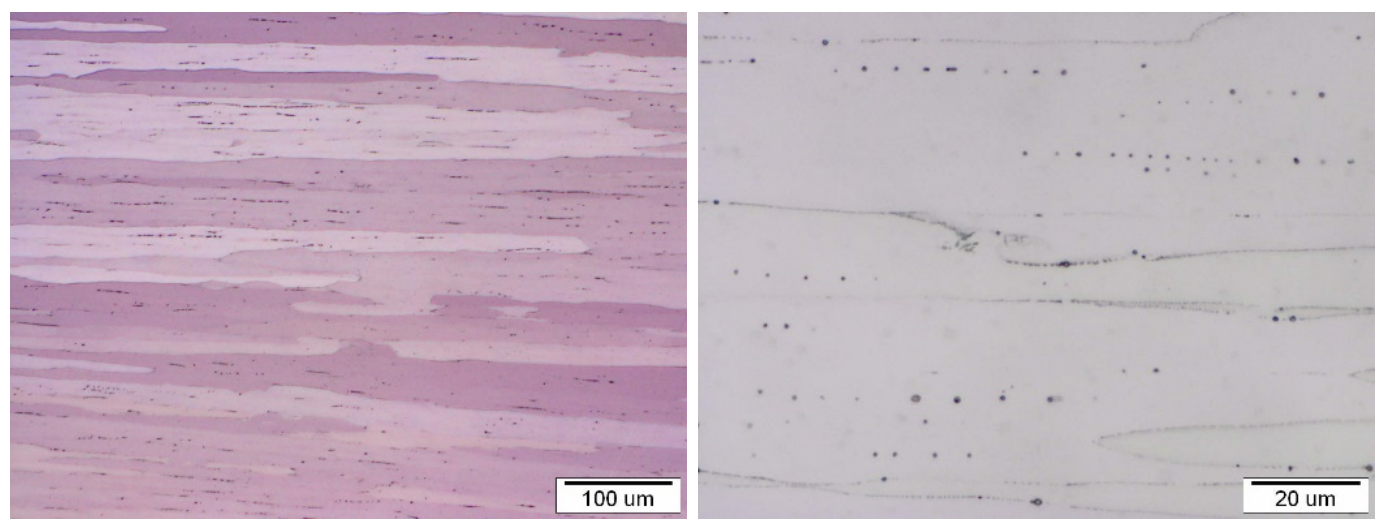

Fig. 5. Microstructure of Al observed at the middle section of the strip
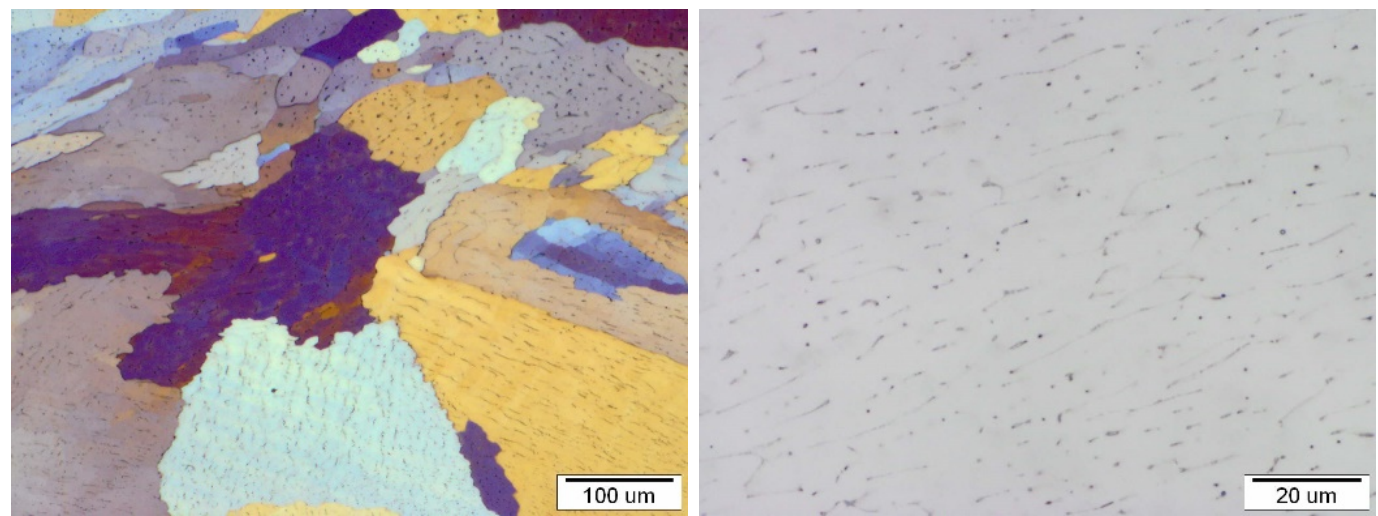

Fig. 6. Microstructure of $\mathrm{AlFe} 0.4$ alloy observed at the edge of the strip
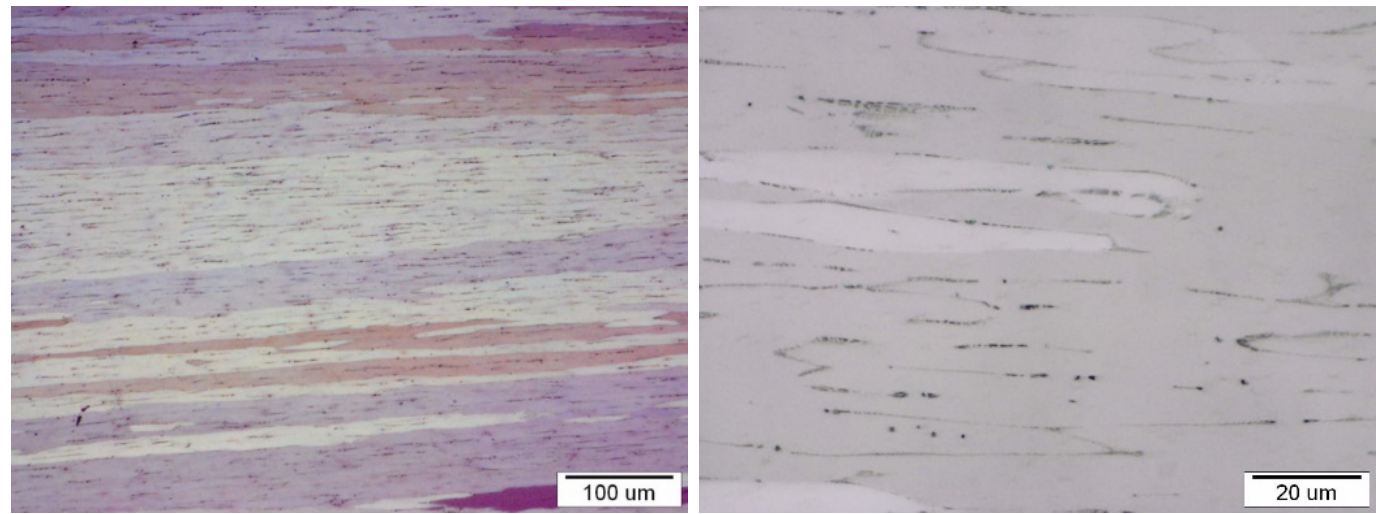

Fig. 7. Microstructure of AlFe 0.4 alloy observed at the middle section of the strip 

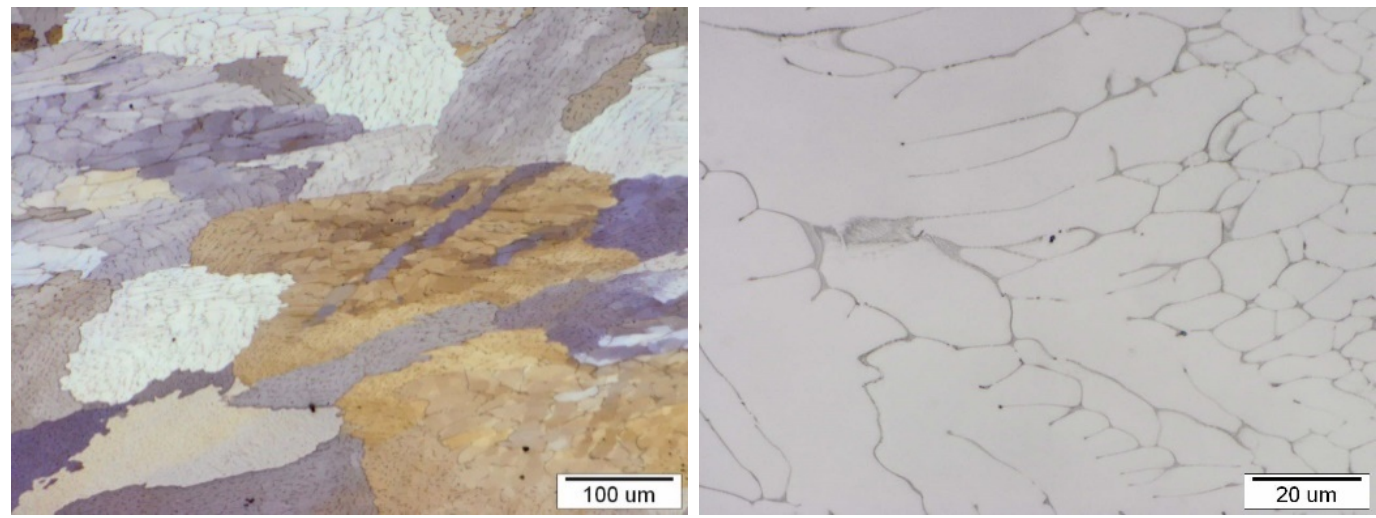

Fig. 8. Microstructure of AlFe 0.73alloy observed at the edge of the strip
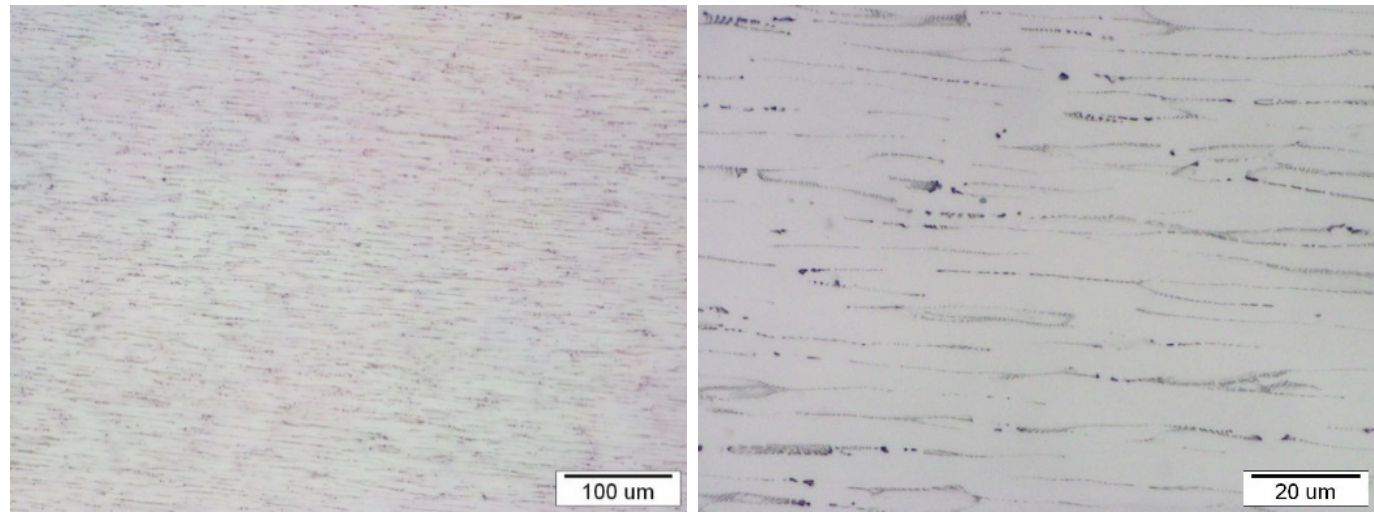

Fig. 9. Microstructure of AlFe 0.73 alloy observed at the middle section of the strip

Obtained results confirm that despite the iron content, each strip shows higher concentration of iron-rich precipitations in its middle section. What is obvious is that with the increased iron content those concentrations are denser and more visible (Figs. 4-9).

At the second stage of the microstructure examination a scanning electron microscope was used which allowed to determine the occurrence of iron in the particular strip areas in a quantitative way. The strip with $0.73 \%$ Fe content was selected for tests as the biggest differences in chemical composition across the thickness were anticipated.

It was found that the observed precipitations contain the base material (aluminium) and iron alone (Fig. 10). There are no signs of silicon, the second alloying element in the examined materials.

The analysis of $\mathrm{Fe}$ content in a strip made of $\mathrm{AlFe} 0.73$ (Fig. 11 and Tab. 2) clearly indicates that higher concentration of iron occurs at the centre axis of the test specimen. These results are compatible line with the hardness test findings.

TABLE 2

Fe content in the AlFe 0.73 strip measured using EDS

\begin{tabular}{|c|c|c|c|}
\hline \hline \multirow{2}{*}{ Measurement area } & \multicolumn{2}{|c|}{ Element content, \% mass } & \multirow{2}{*}{$\begin{array}{c}\text { Measurement } \\
\text { error, \% mass }\end{array}$} \\
\cline { 2 - 3 } & $\mathbf{A l}$ & $\mathbf{F e}$ & $+/-0,12$ \\
\hline Edge & 99,38 & 0,62 & $+/-0,12$ \\
\hline Axial area & 99,07 & 0,93 & \\
\hline
\end{tabular}
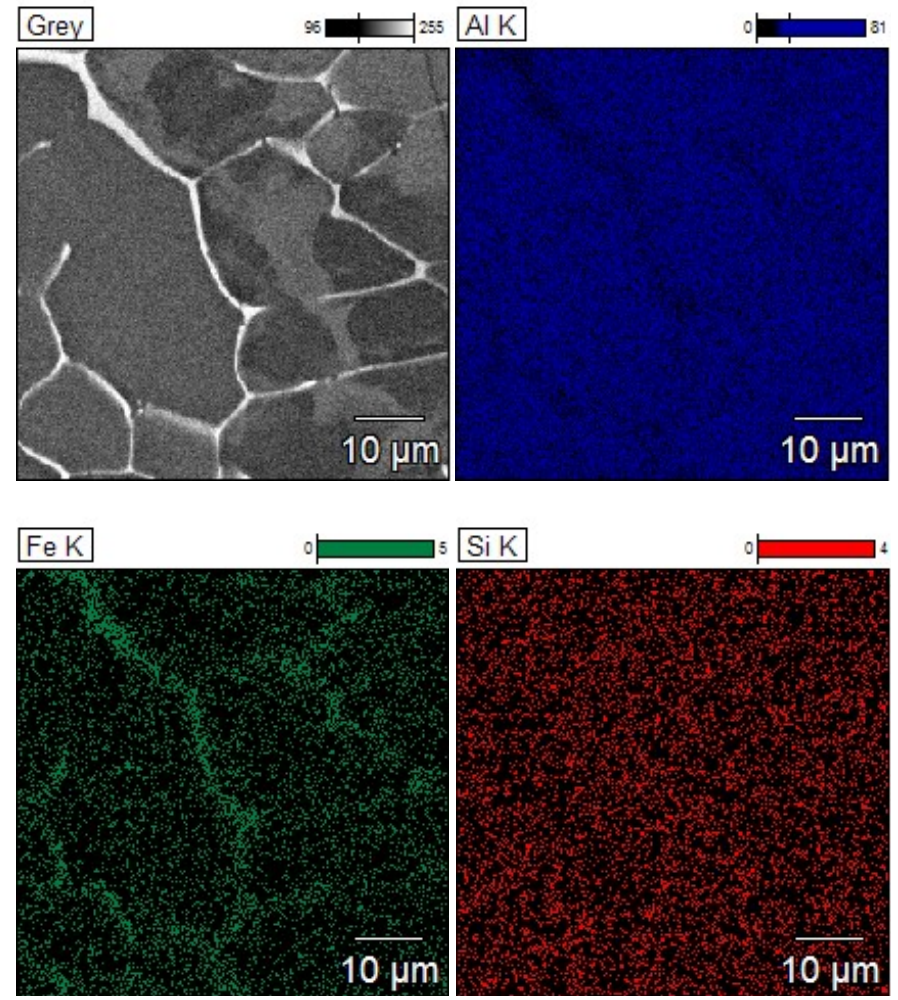

Fig. 10. Analysis of alloying elements distribution in matrix and precipitations in the $\mathrm{AlFe} 0.73$ strip 


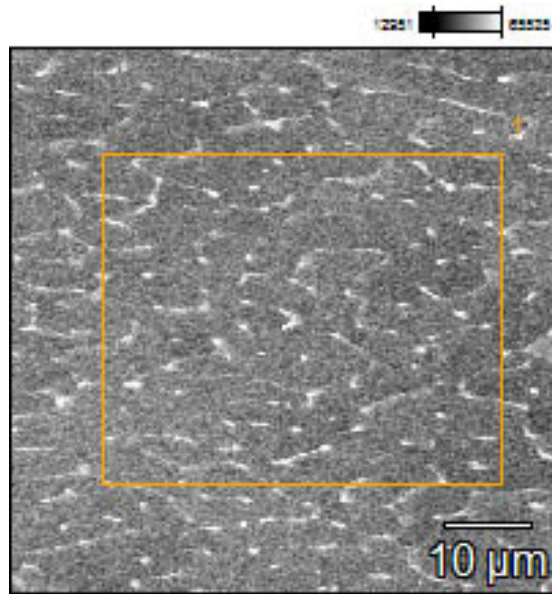

a)

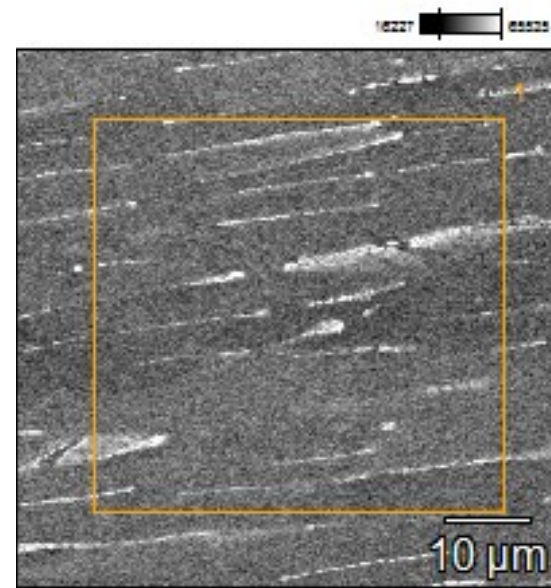

b)

Fig. 11. Fe content analysis in the AlFe0.73 strip - examination at the edge of the test specimen (a) and at the test specimen axis (b)

\subsection{Processing TRC strips into sheets}

In the alternative technology of manufacturing flat products (strips produced by TRC method), the as-cast material is directly subject to a cold rolling process. Therefore, it is essential to determine the properties of the final product $-1 \mathrm{~mm}$ thick, strain-hardened, cold-rolled sheets produced by TRC method. To achieve that, the as-cast strips were cold-rolled.

\section{Energy-force properties for cold rolled alloys series 1XXX and $8 X X X$}

The rolling force measurements were required to calculate the average unit pressure for each of the processed materials (Fig. 12).

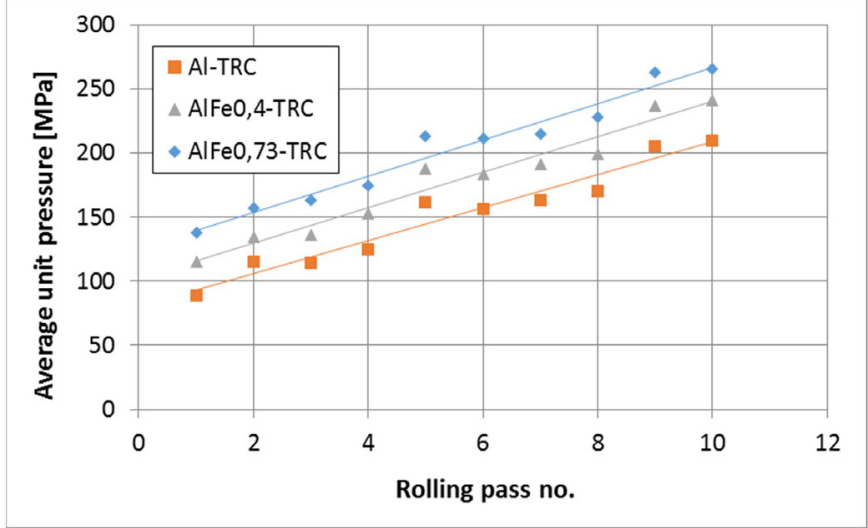

Fig. 12. The average unit pressure during cold rolling process - comparison of different materials produced by TRC

The average unit pressure of metal on the mill cylinders during cold rolling depends on the type of material used, the hardening parameters defined for the pass, the condition of the material prior to processing, friction and dimensions of the rolling gap, as well as the tension and back tension values. The unit pressure increases for the consecutive passes which is a result of strain hardening superposition that raises the plastic strain resistance and the magnitude of unit deflection.

For the three examined materials with different Fe contents manufactured by TRC it was observed that for the individual passes the difference in the average unit pressure is almost constant. The higher plastic resistance of the alloy series 8XXX compared to the alloy series $1 \mathrm{XXX}$ is only a result of hardening caused by alloying elements (Fig. 12).

\section{Examination of changes in mechanical properties of materials during cold rolling}

The cold-rolled test specimens were subject to a hardness test after each rolling pass to present the effects of strain hardening in alloy series $1 \mathrm{XXX}$ and $8 \mathrm{XXX}$ manufactured by TRC (Fig. 13).

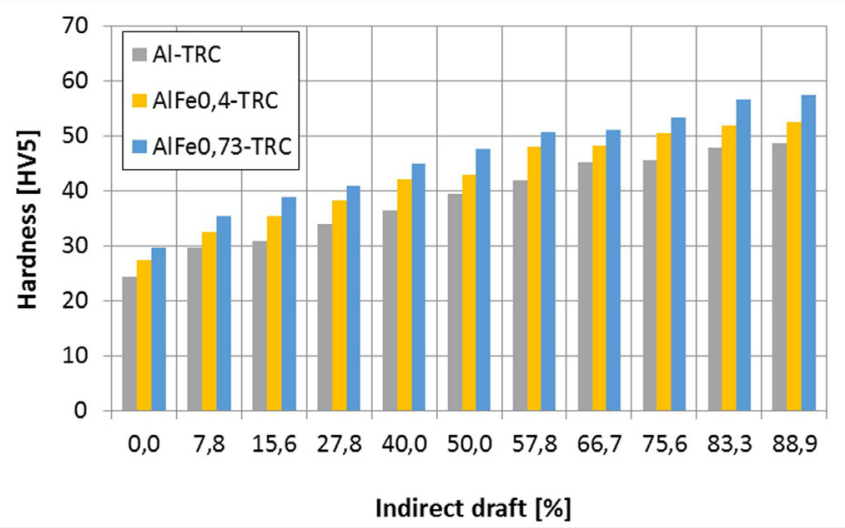

Fig. 13. The evolution of mechanical properties changes during cold rolling - comparison of different materials produced by TRC

It was found that similarly to pure aluminium, the increase in hardness is almost linear and the differences between the examined materials after each rolling pass are similar. The addition of different amounts iron does not have a noticeable impact on the strain hardening of the examined materials. 


\section{Examination of changes in structure for the selected} aluminium alloys during cold rolling

Similarly to the metal strips in an as-cast condition, the metal sheets after the cold rolling process were subject to macroand microstructure examination.

Macrostructure of the aluminium strip after all rolling passes had been completed (Fig. 14). It is worth mentioning that the TRC characteristic structure after all the rolling operations is typical to a structure of a material plastically deformed in the rolling process, i.e. with the grains significantly elongated towards the direction of processing.

Microscopic examination results indicate that introducing iron as an alloying element does not change the structure of the manufactured sheets (Fig. 14). The difference can be seen at the microstructure level (Figs. 15-17), and the findings are similar to those recorded for the as-cast metal strips - the higher the content of iron, the more iron-rich precipitation is observed. Also, their concentration is clearly visible in the middle section of the sheets.

\section{Summary}

As part of the research mechanical and electrical properties and macro- and microstructure of strips made from selected aluminium alloys and manufactured by TRC were examined. Additionally, they were subject to a rolling process (initial thickness of $9 \mathrm{~mm}$, final thickness of $1 \mathrm{~mm}$ ). During that process force parameters were recorded and the evolution of the structure and mechanical and structural properties of the final sheets was examined.

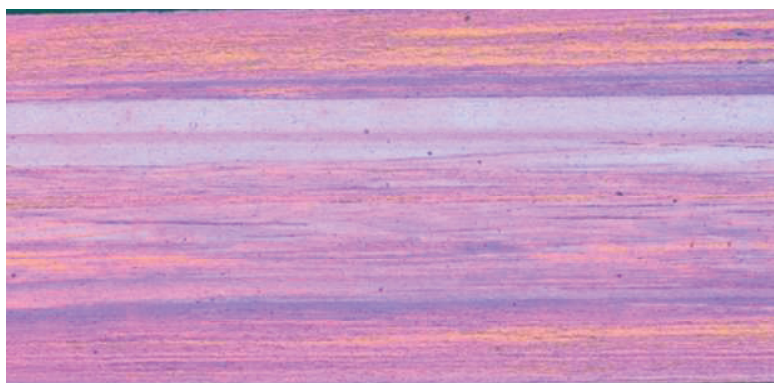

$1 \mathrm{~mm}$

a)

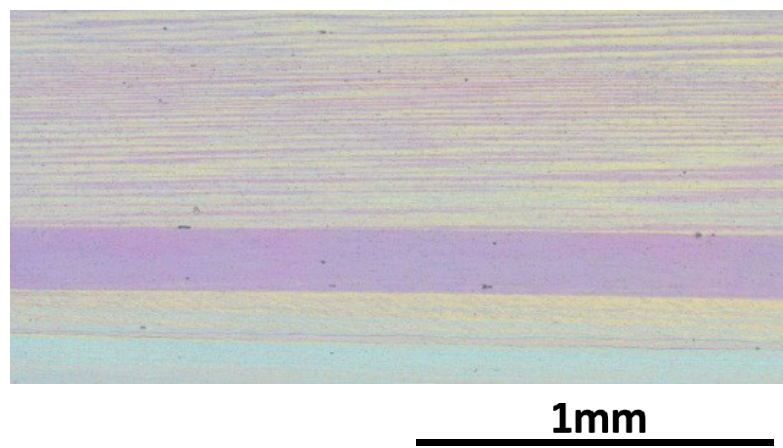

b)

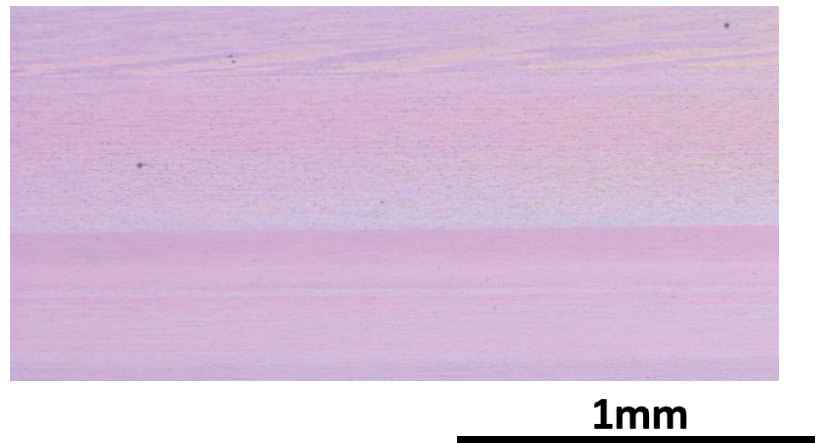

c)

Fig. 14. Macrostructures of metal sheets $1 \mathrm{~mm}$ in thickness made of aluminium alloy series $1 \mathrm{XXX}$ and $8 \mathrm{XXX}$ ( $\mathrm{a}-\mathrm{Al}, \mathrm{b}-\mathrm{AlFe} 0.4, \mathrm{c}-\mathrm{AlFe} 0.73$ )

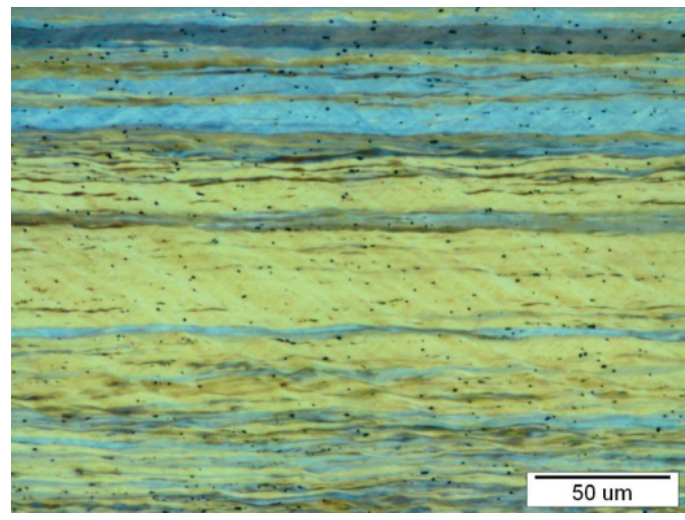

a)

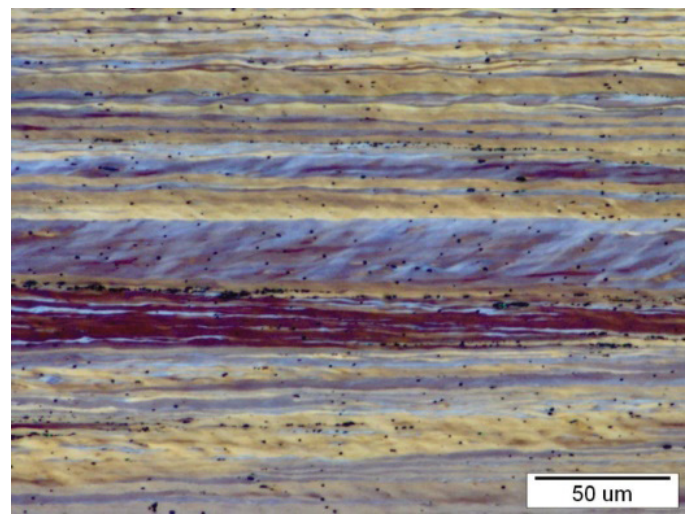

b)

Fig. 15. Microstructure of the $\mathrm{Al}$ observed at the edge (a) and in the middle section (b) of $1 \mathrm{~mm}$ in thickness sheet 


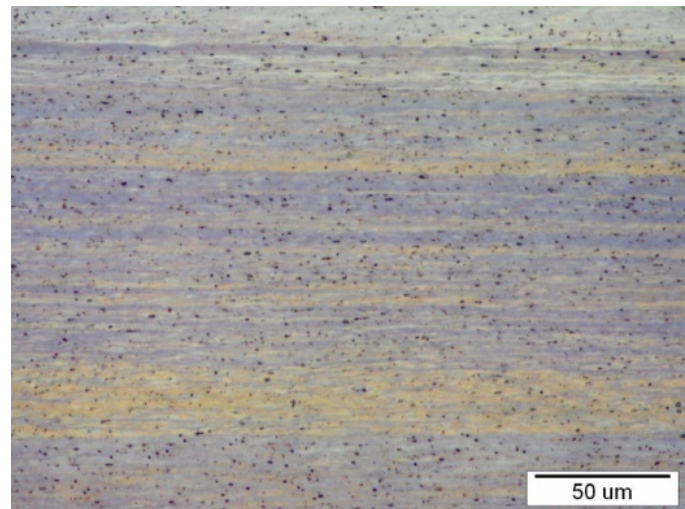

a)

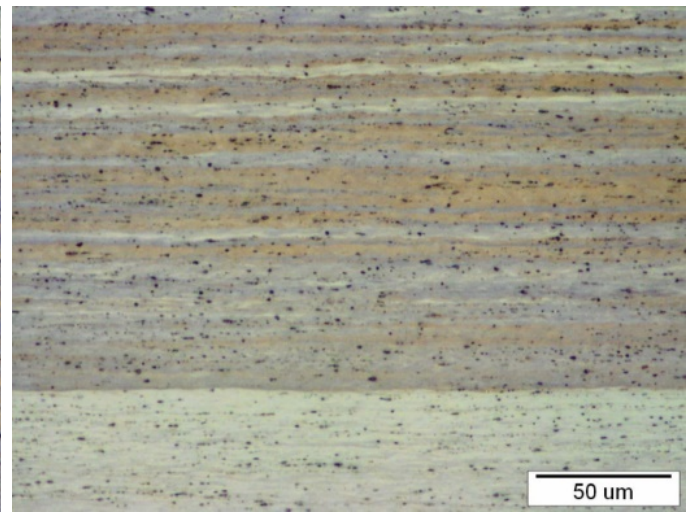

b)

Fig. 16. Microstructure of AlFe 0.4 alloy, observed at the edge (a) and in the middle section (b) of $1 \mathrm{~mm}$ in thickness sheet

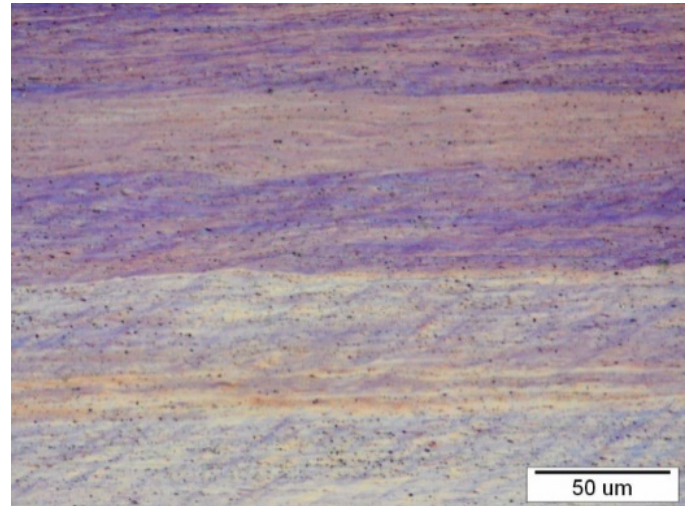

a)

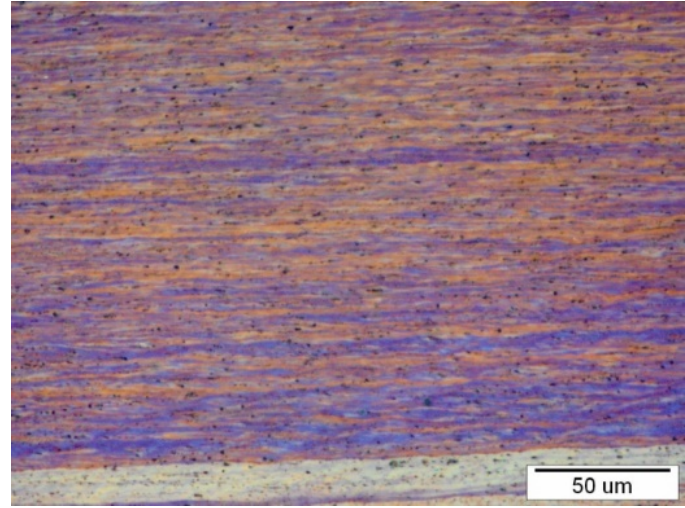

b)

Fig. 17. Microstructure of AlFe 0.73 alloy observed at the edge (a) and in the middle section (b) of $1 \mathrm{~mm}$ in thickness sheet

On the basis of the research results it was found that the hardness of the as-cast metal strips is higher in the middle sections compared to the hardness recorded at the edges. This can be a result of the alloying element segregation phenomenon it the axial area of the casting. It was confirmed by structural examination using an optical microscope (more precipitation was observed in the axial area of the strips) and based on the chemical composition analysis carried out with the use of a scanning microscope.

The analysis of the force parameters from the rolling process leads to the conclusion that for the three strips manufactured by TRC and differing only in the contents of iron the difference in the average unit pressure for each rolling pass is almost constant. Greater plastic resistance was observed in the alloy series $8 \mathrm{XXX}$ over series $1 \mathrm{XXX}$, which only results from the hardening caused by the addition of the alloying elements. Similar observations can be drawn based on the hardening curves obtained from the hardness tests after the individual rolling passes. The analysis of the sheet microstructures after rolling shows that they are typical for a material plastically deformed by rolling, so the grain is substantially elongated in the direction of the processing. In addition, the volume fraction of iron-rich precipitates is observed to be higher in the middle section of the sheet (which is analogous to the microstructure of the material after the casting process).

\section{Acknowledgements}

Research funded by the statutory work: "Advanced processes of synthesis and processing of highly-conductive materials based on non-ferrous metals for use in the energy sector", contract No. 11.11.180. 804/2016, Faculty of Non-Ferrous Metals of the AGH University of Science and Technology

\section{REFERENCES}

[1] D.V. Edmonds, Innovation in the processing of tonnage materials: examples from the steel and aluminium industries, Journal of Materials Processing Technology 83, 1-13 (1998).

[2] S. Ge, M. Isac, R.I.L. Guthrie, Progress of Strip Casting Technology for Steel; Historical Developments, ISIJ International 52 (12), 2109-2122 (2012).

[3] W. Ściężor, T. Knych, A. Mamala, Innowacyjna technologia odlewania stopów aluminium metodą twin roll casting, Innowacyjność akademicka akceleratorem rozwoju nauki i przedsiębiorczości, Monografia pod redakcją Janusza Juraszka i Joanny Kurowskiej-Pysz, Bielsko Biała, 147-162, (2012).

[4] R. Cook, P.G. Grocock, P.M. Thomas, D.V. Edmonds, J.D. Hunt, Development of the twin-roll casting process, Journal of Material Processing Technology 55, 76-84 (1995) 
[5] R.E. Sanders Jr, P.A. Hollinshead, E.A. Simielli, Industrial Development of Non-Heat Treatable Aluminum Alloys, Materials Forum 28, 53-64 (2004).

[6] T. Haga: Development of a twin roll caster for light metals, Journal of Achievements in Materials and Manufacturing Engineering 43, 393-402 (2010)

[7] M. Yun, S. Lokyer, J.D. Hunt, Twin roll casting of aluminum alloys, Materials Science and Engineering A280, 116-123 (2000).

[8] K. Delijić, V. Asanović, D. Radonjić, The Effect of the Thermo-Mechanical Processing on the Properties of some Al-Fe-Si Alloys with High Fe/Si Ratio, Materials Science Forum 555, 559-563 (2007).

[9] Y. Birol, Thermomechanical processing of a twin-roll cast Al$-1 \mathrm{Fe}-0.2 \mathrm{Si}$ alloy, Journal of Materials Processing Technology 202, 564-568 (2008).
[10] C. Kammer, et.al., Thermomechanische Behandlung von A199,5-Gießwalzband, Neue Hütte 35, 418-421 (1990).

[11] A. Mamala, W. Ściężor, Wpływ odkształcenia na zimno oraz obróbki cieplnej na właściwości mechaniczne oraz elektryczne taśm $\mathrm{z}$ aluminium serii $1 \mathrm{xxx}$ oraz 8xxx odlewanych w sposób ciaggły, Rudy i Metale Nieżelazne 57 (9), 604-608 (2012).

[12] A. Mamala, P. Kwaśniewski, T. Knych, W. Ściężor, G. Kiesiewicz, A. Kawecki, Badania własności mechaniczno-elektrycznych blach $\mathrm{z}$ aluminium serii $1 \mathrm{xxx}$ oraz $8 \mathrm{xxx}$ uzyskiwanych $\mathrm{z}$ wsadu odlewanego w układzie ciągłym, Rudy i Metale Nieżelazne 58 (7), 785-789 (2013).

[13] E. Fraś, Krystalizacja metali, WNT, 2004 Warszawa.

[14] L.F. Mondolfo, Metallography of Aluminum Alloys, John Wiley \& Sons, USA (1943). 